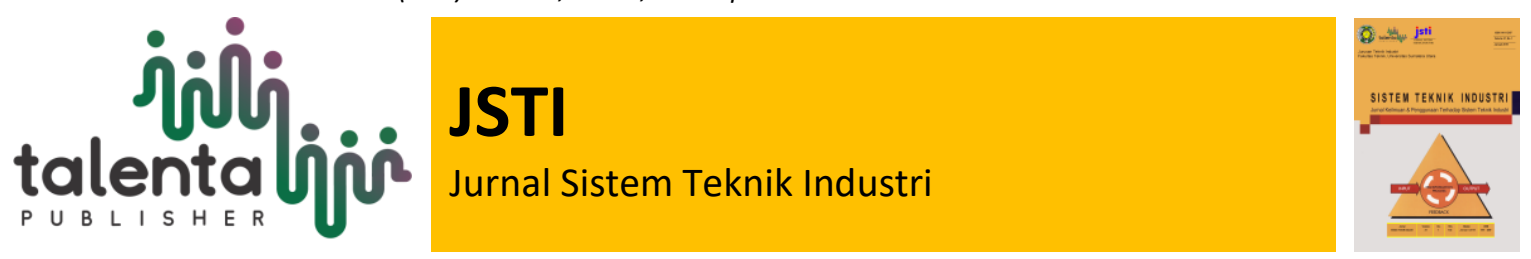

\title{
Desain Relayout Gudang dengan Metode Weighted Distance untuk Meminimasi Travel Time
}

\author{
Adi Firmansyah ${ }^{1}$, Lukmandono $^{2}$ \\ ${ }^{1,2}$ Fakultas Teknik Industri', Institut Teknologi Adhi Tama Surabaya,Surabaya
}

\begin{abstract}
PT IJS merupakan perusahaan yang bergerak dibidang jasa logistik di wilayah Perak Surabaya. PT IJS berdiri sejak tahun 1984 saat kebutuhan akan depo petikemas sangat dibutuhkan di sekitar wilayah pelabuhan tanjung perak untuk menggurai antrian pengiriman barang serta mempersingkat perijinan. Salah satu layanan yang diberikan oleh PT IJS yaitu jasa penyewaan gudang berikat / Bounded Warehouse. Bounded warehouse yang dimiliki PT IJS saat ini belum mampu memberikan pelayanan maksimal dikarenakan masih sering banyaknya pengiriman terlambat yang berimbas tidak terkirimnya barang ke pelabuhan dan terjadi closing time yang merugikan customer. Lamanya proses pengiriman disebabkan beberapa faktor salah satunya yaitu layout gudang yang kurang efektif. Travel time merupakan waktu yang dibutuhkan sebuah kendaraan untuk melakukan kegiatan loading barang di PT. IJS dari kedatangan hingga keluar perusahaan. Berdasarkan perhitungan travel time ketika menggunakan layout awal di peroleh nilai travel time sebesar $\mathrm{T}=2002$ sekon. Metode weighted-distance adalah model matematis yang digunakan untuk mengevaluasi tata letak berdasarkan faktor kedekatan. Perancangan desain relayout dengan menggunakan metode weighted-distance menghasilkan alternatif layout yang menunjukkan perhitungan travel time yang lebih singkat yaitu layout alternatif dengan $\mathrm{T}=1849$ sekon.
\end{abstract}

Keyword: Relayout, Travel Time, Weighted Distance

\begin{abstract}
Abstrak. PT IJS is a company engaged in logistics services in the Perak area of Surabaya. PT IJS was founded in 1984 when the need for container depots was urgently needed around the Tanjung Tanjung port area to unravel the shipping queues and shorten licensing. One of the services provided by PT IJS is bounded warehouse rental services. Bounded warehouse owned by PT IJS is currently not able to provide maximum service because there are still many late deliveries which do not result in the sending of goods to the port and there is a closing time that is detrimental to the customer. The length of the delivery process is due to several factors, one of which is a less effective company layout. Travel time is the time required for a vehicle to carry out goods loading activities at PT. IJS from arrival to exit company. Based on travel time calculations when using the initial layout, the travel time value of $T=2002$ seconds. The weighted-distance method is a mathematical model used to evaluate the layout based on proximity factors. The design of the relayout design using the weighted-distance method produces alternative layouts that produce shorter travel time calculations, alternative layout with $T=1849$ seconds.
\end{abstract}

Kata Kunci: Relayout, Travel Time, Weighted Distance

Received 12 Desember 2019| Revised 20 Januari 2020 | Accepted 27 Januari 2020

*Corresponding author at: Jl. Sukorejo baru RT 11 RW 04, Sukorejo, Buduran, Sidoarjo 61252

E-mail address: firman.harvest@gmail.com, lukmandono@itats.ac.id 


\section{Introduction}

Persaingan dunia usaha kini makin ketat, setiap usaha dituntut untuk melakukan kegiatan usaha secara efektif dan efisien. Dalam suatu pabrik, efektif dan efisien dapat dilihat melalui berbagai aspek diantaranya sistem penyimpanan material. Misalnya gudang bahan baku, ketersediaan bahan baku pada waktu yang tepat dan jumlah yang tepat dapat mempengaruhi kelancaran proses produksi [1].

Tata letak perusahaan termasuk aspek utama dalam dunia industri karena berkaitan erat dengan cara pengaturan fasilitas-fasilitas perusahaan. Pengaturan tata letak perusahaan yang optimal akan berkontribusi terhadap kelancaran seluruh operasi perusahaan. Artinya tata letak perusahaan yang baik dapat menempatkan berbagai fasilitas dan peralatan fisik secara teratur sehingga mendukung pekerjaan berjalan secara produktif [2].

Perencanaan tata letak fasilitas meliputi penentuan lokasi sistem manufaktur dan perencanaan fasilitas yang meliputi perancangan terhadap fasilitas, tata letak, serta penanganan bahan yang mendukung aktivitas produksi di sebuah perusahaan. Tata letak adalah suatu landasan utama dalam dunia industri. Tata letak pabrik (plant layout) atau tata letak fasilitas (facilities layout) dapat didefinisikan sebagai tata cara pengaturan fasilitas-fasilitas pabrik guna menunjang kelancaran proses produksi [3].

Didalam sistem pelayanan perusahaan logistik sering kali membutuhkan travel time yang cukup lama, yang berimbas pada tersendatnya proses supply chain dan menimbulkan kerugian. Travel time didalam perusahaan dapat terjadi karena layout perusahaan yang diterapkan oleh perusahaan belum efektif hal ini disebabkan layout yang diterapkan secara kondisional. Faktor ini menyebabkan lamanya proses kegiatan loading barang di dalam gudang sehingga proses pengiriman yang telah dijadwalkan sering terlambat.

PT IJS melayani berbagai macam kegiatan logistik perusahaan - perusahaan yang membutuhkan jasa pengiriman eksport import. Salah satu layanan yang diberikan oleh PT IJS yaitu jasa penyewaan gudang berikat / Bounded Warehouse. Sistem Bounded Warehouse yang dimiliki oleh PT IJS berkaitan erat dengan bea cukai, dimana segala kegiatan yang dilakukan diwilayah berikat harus mengikuti seluruh aturan yang berlaku, salah satunya yaitu ketepatan waktu pengiriman dan kecepatan pelayanan

Bounded warehouse yang dimiliki PT IJS saat ini dirasa masih belum mampu memberikan pelayanan maksimal dikarenakan masih banyaknya pengiriman yang terlambat sehingga berimbas tidak terkirimnya barang ke pelabuhan dan terjadi closing time yang merugikan customer. Berdasarkan data pengiriman barang PT IJS selama periode Juni 2019 telah terjadi 36 kali klaim keterlambatan oleh customers dari 53 kali pengiriman. 
Faktor yang menjadi penyebab terhambatnya proses pengiriman yaitu layout gudang yang kurang efektif dikarenakan masih mempertahankan layout gudang sejak awal berdirinya perusahaan. Perlu adanya perubahan layout gudang mengingat semakin tingginya jumlah kegiatan loading barang didalam perusahaan setiap harinya.

\section{Literatur Review}

\subsection{Tata Letak Perusahaan}

Tata letak fasilitas dapat didefinisikan sebagai suatu kegiatan merencanakan atau menyusun fasilitas sebuah industri secara optimal yang meliputi tenaga kerja, alat angkut, departemen produksi, gudang penyimpanan bahan baku, gudang bahan jadi dan semua fasilitas pendukung yang sesuai dengan rancangan struktur terbaik yang terdiri dari fasilitas ini. Perancangan fasilitas merupakan kegiatan mengevaluasi, menganalisis, membentuk konsep dan mewujudkan sistem bagi pembuatan barang dan jasa, dengan kata lain, merupakan pengaturan tempat sumber daya fisik yang digunakan untuk membuat produk [4]

Tata letak perusahaan dapat didefinisikan sebagai tata cara pengaturan fasilitas-fasilitas perusahaan dengan memanfaatkan luas area secara optimal guna menunjang kelancaran proses produksi. Pengaturan tata letakpabrik dapat meningkatkan efisiensi dan efektivitas produksi sehingga kapasitas dan kualitas produksi yang direncanakan dapat dicapai dengan tingkat biaya yang paling ekonomis.Tata letak pabrik adalah tata cara pengaturan fasilitas-fasilitas pabrik dengan memanfaatkan luas area secara optimal guna menunjang kelancaran proses produksi [5].

Desain tata letak perusahaan yang baik yaitu yang mampu memperpendek jarak dan meminimumkan biaya material handling sehingga memberikan keuntungan lebih besar kepada perusahaan (Lukmandono, 2018). Hal utama yang harus diperhatikan dalam merancang tata letak gudang yaitu tempat penemrimaan barang, area untuk penyimpanan, pemilihan, dan pengiriman barang [6].

\subsection{Travel Time}

Travel Time dari suatu ruas jalan merupakan salah satu acuan yang dapat digunakan dalam merencanakan suatu perjalanan. Informasi perkiraan waktu perjalanan sangat berguna bagi pengguna jalan untuk memilih rute perjalanan yang dapat mempermudah untuk sampai ke tujuan. Untuk itu dibutuhkan suatu estimasi travel time yang dapat diandalkan [7] Metode estimasi travel time dapat diperkirakan dengan survei langsung di lapangan dan dapat juga diperoleh dari pemodelan waktu perjalanan Kecepatan rata-rata waktu adalah kecepatan rata-rata dari seluruh kendaraan yang melewati suatu titik dari jalan selama periode waktu tertentu. Model pengukuran travel time yang digunakan pada penelitian ini adalah Instantaneous Model yang termasuk kedalam indirect methods dan bagian dari theorical techniques. Instantaneous Model atau Model seketika adalah metode estimasi waktu perjalanan yang menggunakan data kecepatan setempat 
yang dikumpulkan dari setiap link pada saat $\mathrm{k}$. Waktu tempuh untuk setiap link dihitung sebagai panjang link dibagi dengan rata-rata kecepatan sesaat di hulu dan hilir link, dengan perumusan sebagai berikut:

$$
\mathrm{t}(\mathrm{i}, \mathrm{k})=\frac{2 l i}{v(i a, k)+v(i b, k)}
$$

Dengan:

li

$$
=\text { Panjang link }(\mathrm{km})
$$

$\mathrm{v}(\mathrm{ia}, \mathrm{k}) \quad=$ Kecepatan di hulu link i pada waktu $\mathrm{k}(\mathrm{km} / \mathrm{jam})$

$\mathrm{v}(\mathrm{ib}, \mathrm{k}) \quad=$ Kecepatan di hilir link i pada waktu $\mathrm{k}(\mathrm{km} / \mathrm{jam})$

$\mathrm{t}(\mathrm{i}, \mathrm{k}) \quad=$ Waktu Perjalanan

\subsection{Weighted Distance Method}

The weighted-distance method adalah model matematis yang digunakan untuk mengevaluasi tata letak berdasarkan faktor kedekatan. Penerapan metoda ini dapat dilakukan dengan menggunakan euclidean distance atau rectilinear distance. Jarak euclidean merupakan jarak yang diukur lurus antara pusat fasilitas satu dengan pusat fasilitas lainnya. Sistem pengukuran dengan jarak euclidean sering digunakan karena lebih mudah dimengerti dan mudah digunakan (Muslim, 2018). Contoh aplikasi pada beberapa model conveyor, dan juga jaringan transportasi dan distribusi (Pratiwi, 2012). Perhitungan jarak rectilinier antara i dan j seperti berikut [10] :

$$
\begin{aligned}
& \mathrm{d}_{\mathrm{ij}}=\sqrt{ }\left[(x 2-x 1)^{2}+(y 2-y 1)^{2}\right] \\
& \mathrm{d}_{\mathrm{ij}}=|x-a|+|y-b|
\end{aligned}
$$

RECTILINER DISTANCE

$$
d A B=|X a-X b|+|Y a-Y b|
$$

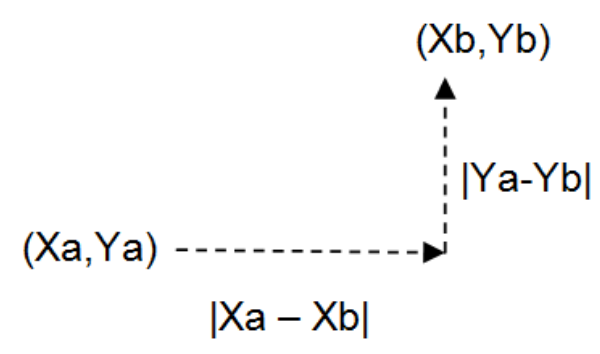

Gambar 1 Rectilinier Distance

\section{Metodologi Penelitian}

Langkah penyelesaian masalah dalam penelitian ini yaitu dengan mendesain layout alternatif dengan metode weighted distance dan membandingkan hasil perhitungan travel timenya dengan layout awal.

\subsection{Pengumpulan Data}

Data yang diperlukan dalam penelitan yaitu sebagai berikut :

a. Data perusahaan (profil, lokasi, ruang lingkup, layout perusahaan awal) 
b. Data jadwal dan jumlah loading

c. Data alur kegiatan pengiriman di dalam perusahaan

d. Data frekuensi dan alur kegiatan loading barang

e. Data waktu proses kegiatan loading barang

\subsection{Pengolahan Data}

Setelah data terkumpul maka dilakukan pengolahan data dengan menghitung travel time yang dibutuhkan berdasarkan layout awal. Kemudian menggunakan pendekatan metode weighted distance untuk menentukan layout perusahaan usulan dan menghitung travel time berdasarkan layout usulan. Langkah terakhir yaitu membandingkan travel time antara layout awal dengan perhitungan travel time dengan menggunakan layout usulan.

Metode yang digunakan untuk menyelesaikan salah satu rumusan masalah yaitu Weighted Distance Method. Metode ini terdiri dari beberapa urutan pengerjaan sebagai berikut :

1. Informasi perusahaan
a. Profil PT. IJS
b. Layout awal perusahaan dan layout gudang
c. Data ruang dan fasilitas perusahaan
d. Data travel time saat layout awal
e. Frekuensi aliran dan perpindahan barang

2. Aliran material handling, yaitu data pola aliran material di PT IJS dan hubungan aktivitas dengan derajat kedekatan antar ruangan.

3. Matriks kedekatan akitivtas, yaitu sebuah tabel yang memberikan suatu ukuran relatif pentingnya setiap pasangan ruang yang terletak berdekatan.

4. Ketersediaan ruang merupakan data fasilitas yang terdapat di dalam ruangan sehingga didapatkan data luasan yang dibutuhkan.

5. Perancangan layout baru dengan menggembangkan block plan mempertimbangkan frekuensi material handling dan matriks kedekatan hubungan aktivitas tiap ruang.

6. Evaluasi Metode, perbadingan antara layout awal dengan layout baru dengan hasil yang dapat meminimasi travel time.

\section{Analisis Dan Pembahasan}

\subsection{Informasi Perusahaan}

PT IJS merupakan perusahaan jasa yang bergerak dibidang logistik. PT IJS melayani beberapa aktivitas logsitik di wilayah Surabaya dan sekitarnya. PT IJS didukung berbagai fasilitas dan peralatan angkut yang lengkap dan modern. Untuk aktivitas logsitik PT IJS melayani berbagai macam kegiatan, yang utama yaitu depo kontainer dan penyewaan gudang berikat (PLB). Berikut layout awal PT IJS yang berhubungan langsung dengan kegiatan loading barang : 


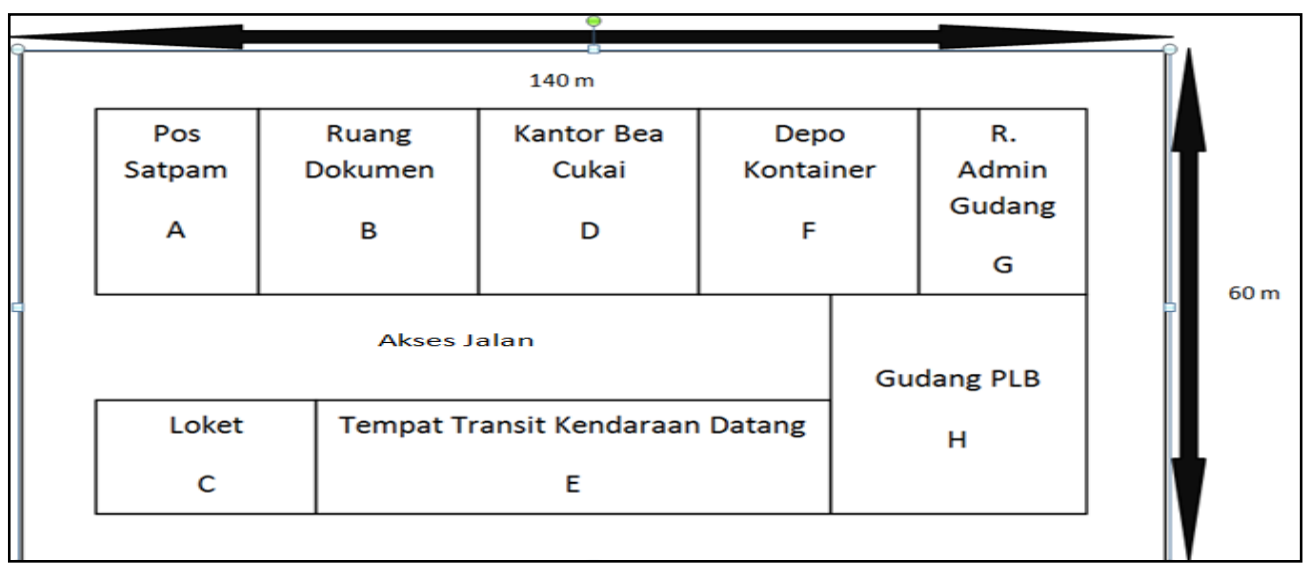

Gambar 2 Layout awal Perusahaan PT IJS

\subsection{Aliran Proses Kegiatan Loading}

Lama proses kegiatan yang dijadikan refrensi penelitian merupakan hasil dari rata - rata waktu lama proses kegiatan loading selama 20 hari kerja di bulan Juli 2019. Berikut data hasil pengamatan lama waktu proses kegiatan di tiap departemen :

Tabel 1 Data Waktu Proses Kegiatan Loading Barang

\begin{tabular}{|c|c|c|c|c|}
\hline No & Departemen & Kegiatan & Pelaksana & Lama Proses \\
\hline 1 & $\mathrm{~A}$ & $\begin{array}{l}\text { Proses Perijinan dan } \\
\text { Pengecekan Surat - } \\
\text { surat kendaraan }\end{array}$ & $\begin{array}{l}\text { Satpam dan Sopir } \\
\text { Kontainer }\end{array}$ & 5 Menit \\
\hline 2 & B & $\begin{array}{l}\text { Pembuatan dokumen } \\
\text { bea cukai }\end{array}$ & Admin Bea cukai & 30 menit \\
\hline 3 & $\mathrm{C}$ & $\begin{array}{l}\text { Pengambilan nomer } \\
\text { antrian stuffing dan } \\
\text { Pengecekan dokumen }\end{array}$ & Admin Loket & 10 menit \\
\hline 4 & $\mathrm{D}$ & $\begin{array}{c}\text { Proses Legalisasi } \\
\text { Dokumen dan } \\
\text { pengambilan segel bea } \\
\text { cukai }\end{array}$ & $\begin{array}{l}\text { Petugas Bea } \\
\text { Cukai }\end{array}$ & 10 Menit \\
\hline 5 & $\mathrm{E}$ & $\begin{array}{l}\text { Tempat menunggu } \\
\text { untuk siap dipanggil } \\
\text { stuffing sesuai nomer } \\
\text { urutan }\end{array}$ & Satpam & $1 \mathrm{jam}$ \\
\hline 6 & $\mathrm{~F}$ & $\begin{array}{c}\text { Pengambilan } \\
\text { kontainer yang akan } \\
\text { digunakan stuffing } \\
\text { sesuai surat jalan }\end{array}$ & $\begin{array}{c}\text { Oprator } \\
\text { Reachtruck }\end{array}$ & 5 menit \\
\hline 7 & G & $\begin{array}{l}\text { Pembuatan dokumen } \\
\text { surat jalan dan } \\
\text { finalisasi dokumen }\end{array}$ & Admin gudang & 30 menit \\
\hline 8 & $\mathrm{H}$ & Proses stuffing barang & Petugas Gudang & $1 \mathrm{jam}$ \\
\hline
\end{tabular}

Untuk mengetahui waktu tempuh yang diperlukan untuk mencapai departemen satu ke departemen yang lain maka dilakukan observasi dan pengukuran waktu tempuh dilapangan. Waktu tempuh antar lokasi diatas diperoleh dari rata - rata waktu yang dibutuhkan oleh seorang 
petugas masing -masing departemen untuk menempuh perjalanan dari departemen satu ke departemen yang lain. Data waktu tempuh diatas digunakan sebagai acuan penentuan travel time untuk setiap perpindahan antar departemen pada layout awal dan layout usulan. Tabel 2 menjelaskan tentang proses aliran antar departemen di PT IJS dengan waktu tempuh yang dibutuhkan dari satu departemen ke departemen yang lain berdasarkan layout saat ini :

Tabel 2 Data Waktu Tempuh Antar Departemen

\begin{tabular}{ccccccccc}
\hline Dari & \multicolumn{7}{c}{ Waktu tempuh ke departemen (s) } \\
\cline { 2 - 9 } & A & B & C & D & E & F & G & H \\
\hline A & - & 60 & 60 & 120 & 120 & 180 & 240 & 250 \\
B & & - & 60 & 60 & 60 & 120 & 180 & 190 \\
C & & & - & 120 & 120 & 180 & 250 & 260 \\
D & & & & - & 60 & 60 & 120 & 130 \\
E & & & & & - & 100 & 130 & 120 \\
F & & & & & & - & 60 & 70 \\
G & & & & & & & - & 60 \\
H & & & & & & & & - \\
\hline
\end{tabular}

\subsection{Matriks Kedekatan}

Tabel 3 Matriks Kedekatan Anatar Departemen

\begin{tabular}{|c|c|c|c|c|c|c|c|c|c|}
\hline \multirow[t]{2}{*}{ No } & \multirow[t]{2}{*}{ Departemen } & \multicolumn{8}{|c|}{ Interaksi antar ruang } \\
\hline & & A & B & $\mathrm{C}$ & $\mathrm{D}$ & $\mathrm{E}$ & $\mathrm{F}$ & G & $\mathrm{H}$ \\
\hline 1 & A & - & 2 & 4 & 1 & 3 & 2 & 2 & 2 \\
\hline 2 & B & & - & 2 & 5 & 1 & 2 & 5 & 3 \\
\hline 3 & $\mathrm{C}$ & & & - & 2 & 4 & 3 & 3 & 2 \\
\hline 4 & $\mathrm{D}$ & & & & - & 1 & 2 & 3 & 2 \\
\hline 5 & $\mathrm{E}$ & & & & & - & 4 & 3 & 4 \\
\hline 6 & $\mathrm{~F}$ & & & & & & - & 2 & 4 \\
\hline 7 & $\mathrm{G}$ & & & & & & & - & 5 \\
\hline 8 & $\mathrm{H}$ & & & & & & & & - \\
\hline
\end{tabular}

Tabel 4 Derajat Kedekatan, Bobot, Dan Deskripsi Kedekatan

\begin{tabular}{|c|c|c|c|}
\hline No & Derajat kedekatan & Bobot & Deskirpsi alasan \\
\hline 1 & Mutlak perlu didekatkan & 5 & $\begin{array}{l}\text { Terdapat aliran dokumen penting dan } \\
\text { kontak bersama }\end{array}$ \\
\hline 2 & Penting didekatkan & 4 & $\begin{array}{l}\text { Sering melakukan pemindahan dokumen } \\
\text { dan kontak bersama }\end{array}$ \\
\hline 3 & Cukup / biasa & 3 & Ada kontak dan pemidahan dokumen \\
\hline 4 & Tidak penting didekatkan & 2 & Jarang melakukan kontak bersama \\
\hline 5 & $\begin{array}{l}\text { Tidak dikehendaki untuk } \\
\text { didekatkan }\end{array}$ & 1 & $\begin{array}{c}\text { Tidak ada pemindahan dokumen dan } \\
\text { kontak bersama }\end{array}$ \\
\hline
\end{tabular}

Berdasarkan analisis matrix kedekatan diatas maka dapat diperoleh informasi bahwa : 
1) Departemen yang harus diletakkan berdekatan yaitu departemen $B$ dan G, B dan $\mathrm{D}, \mathrm{G}$ dan $\mathrm{H}$.

2) Departemen yang tidak boleh didekatkan yaitu departemen A dan D, B dan E.

3) Departemen yang dapat di dekatkan yaitu departemen A dan C, C dan E, E dengan $\mathrm{F}$ dengan $\mathrm{H}$.

4) Departemen yang tidak perlu didekatkan yaitu departemen A dengan B,F,G,H. Departemen B dengan C,F. Departemen C dengan D,H. Departemen D dengan F,H. Departemen F dengan G.

5) Untuk hubungan kedekatan departemen lain berdasarkan matrix kedekatan yang berwarna kuning bersifat opsional yaitu dapat dipindah atau tidak dipindah.

6) Catatan dari PT IJS bahwa untuk departemen $\mathrm{H}$ yaitu gudang utama tidak boleh dipindahkan karena fasilitas dan struktur bangunan yang permanen dan tidak bisa dipindahkan.

\subsection{Menyusun Block Plan dan Layout Alternatif}

Block plan merupakan rancangan yang digunakan untuk menyusun ruang atau blok departemen dengan menunjukkan penempatan masing-masing ruang tersebut. Berdasarkan informasi ketersediaan ruang yang telah diperolah dari hasil observasi serta mempertimbangkan matrix kedekatan antar departemen maka dapat disusun block plan sebagai acuan yang lebih mudah untuk menentukan layout usulan. Penyusunan current block plan berdasarkan layout saat ini yaitu sebagai berikut :

\begin{tabular}{lllll}
\hline A & B & D & F & G \\
C & & E & & H \\
\hline
\end{tabular}

Gambar 4 Block Plan Berdasarkan Layout Awal

Berdasarkan current block plan dan matrix kedekatan maka dapat disusun proposed block plan pertama dengan catatan departemen $\mathrm{H}$ atau gudang tidak boleh dipindahkan seperti pada informasi sebelumnya dan dengan mempertimbangkan kesimpulan 1 dan 2 pada matrix kedekatan yaitu :

1) Departemen yang harus diletakkan berdekatan yaitu departemen B dan G, B dan $\mathrm{D}, \mathrm{G}$ dan $\mathrm{H}$.

2) Departemen yang tidak boleh didekatkan yaitu departemen A dan D, B dan E. Pertimbangan diatas diimplementasikan dalam proposed block plan pertama sebagai berikut:

\begin{tabular}{ccccc}
\hline A & F & D & B & G \\
C & & E & & H \\
\hline
\end{tabular}


Langkah selanjutnya yaitu merancang proposed block plan menjadi layout usulan sesuai kebutuhan departemen dan ketersediaan ruang yang ada. Berdasarkan kebutuhan masing-masing ruang, maka dapat disusun layout usulan berdasarkan proposed block plan yaitu sebagai berikut

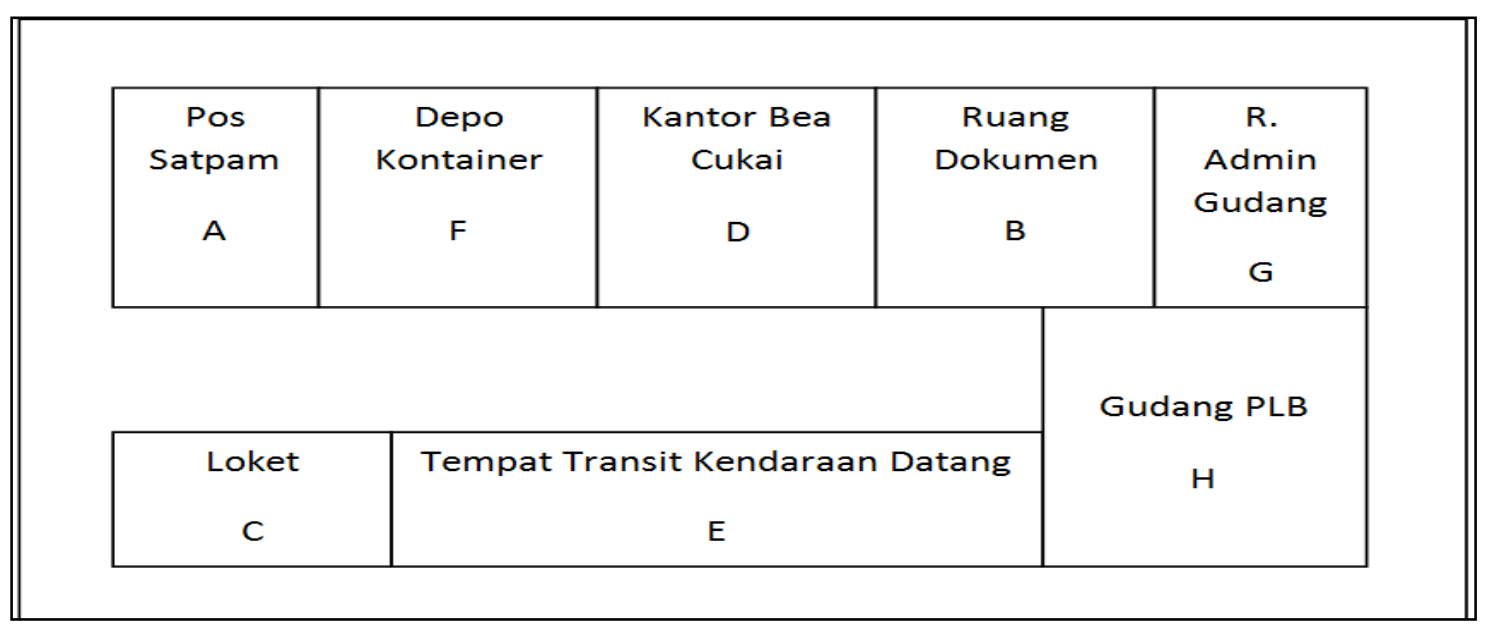

Gambar 6 Layout Alternatif Berdasarkan Proposed Block Plan

\subsection{Evaluasi Metode}

Untuk menentukan apakah proposed block plan ini dapat diterima atau tidak maka dilakukan evaluasi metode weigted distance dengan mengukur rectiliner distance (d) dan bobot jarak (wd). Untuk perhitungan rectiliner distance menggunakan rumus sebagai berikut :

$$
\operatorname{dij}=|x-a|+|y-b|
$$

sedangkan bobot jarak (wd) diperoleh dengan menggalikan besar jarak (d) dengan faktor kedekatan $(\mathrm{wd})$. Sehingga diperoleh rumus bobot jarak atau weighted distance sebagai berikut :

$$
\mathrm{wd}=(\mathrm{d}) *(\mathrm{w})
$$

berdasarkan rumus diatas maka diperoleh nilai (wd) untuk masing-masing hubungan antar departemen sebagai berikut

Tabel 5 Hasil Perhitungan Weighted Distance

\begin{tabular}{cccccc}
\hline $\begin{array}{c}\text { Pasangan } \\
\text { Ruang }\end{array}$ & $\begin{array}{c}\text { Faktor } \\
\text { kedekatan, (w) }\end{array}$ & \multicolumn{2}{c}{ Current Block Plan } & \multicolumn{2}{c}{ Proposed Block Plan } \\
& & Distance (d) & Wd score & Distance (d) & Wd Score \\
\hline A,B & 2 & 1 & 2 & 2 & 4 \\
A,C & 4 & 1 & 4 & 1 & 4 \\
A,D & 1 & 2 & 2 & 2 & 2 \\
A,E & 3 & 2 & 6 & 2 & 6 \\
A,F & 2 & 3 & 6 & 1 & 2 \\
A,G & 2 & 4 & 8 & 4 & 8 \\
\hline
\end{tabular}


Tabel 5 Hasil Perhitungan Weighted Distance (Lanjutan)

\begin{tabular}{|c|c|c|c|c|c|}
\hline \multirow{3}{*}{$\begin{array}{l}\text { Pasangan } \\
\text { Ruang }\end{array}$} & \multirow{3}{*}{$\begin{array}{c}\text { Faktor } \\
\text { kedekatan, (w) }\end{array}$} & \multicolumn{2}{|c|}{ Current Block Plan } & \multirow{2}{*}{\multicolumn{2}{|c|}{$\begin{array}{c}\text { Proposed Block Plan } \\
\text { I }\end{array}$}} \\
\hline & & \multirow[b]{2}{*}{ Distance (d) } & \multirow[b]{2}{*}{ Wd score } & & \\
\hline & & & & Distance (d) & Wd Score \\
\hline $\mathrm{A}, \mathrm{H}$ & 2 & 5 & 10 & 5 & 10 \\
\hline $\mathrm{B}, \mathrm{C}$ & 2 & 1 & 2 & 3 & 6 \\
\hline $\mathrm{B}, \mathrm{D}$ & 5 & 1 & 5 & 1 & 5 \\
\hline $\mathrm{B}, \mathrm{E}$ & 1 & 1 & 1 & 2 & 2 \\
\hline $\mathrm{B}, \mathrm{F}$ & 2 & 2 & 4 & 2 & 4 \\
\hline $\mathrm{B}, \mathrm{G}$ & 5 & 3 & 15 & 1 & 5 \\
\hline $\mathrm{B}, \mathrm{H}$ & 3 & 4 & 12 & 1 & 3 \\
\hline $\mathrm{C}, \mathrm{D}$ & 2 & 3 & 6 & 3 & 6 \\
\hline $\mathrm{C}, \mathrm{E}$ & 4 & 2 & 8 & 2 & 8 \\
\hline $\mathrm{C}, \mathrm{F}$ & 3 & 3 & 9 & 1 & 3 \\
\hline $\mathrm{C}, \mathrm{G}$ & 3 & 4 & 12 & 4 & 12 \\
\hline $\mathrm{C}, \mathrm{H}$ & 2 & 4 & 8 & 4 & 8 \\
\hline $\mathrm{D}, \mathrm{E}$ & 1 & 1 & 1 & 1 & 1 \\
\hline $\mathrm{D}, \mathrm{F}$ & 2 & 1 & 2 & 1 & 2 \\
\hline $\mathrm{D}, \mathrm{G}$ & 3 & 2 & 6 & 2 & 6 \\
\hline $\mathrm{D}, \mathrm{H}$ & 2 & 3 & 6 & 3 & 6 \\
\hline E,F & 4 & 2 & 8 & 1 & 4 \\
\hline E,G & 3 & 3 & 9 & 3 & 9 \\
\hline E,H & 4 & 3 & 12 & 3 & 12 \\
\hline $\mathrm{F}, \mathrm{G}$ & 2 & 1 & 2 & 3 & 6 \\
\hline $\mathrm{F}, \mathrm{H}$ & 4 & 1 & 4 & 4 & 16 \\
\hline $\mathrm{G}, \mathrm{H}$ & 5 & 1 & 5 & 1 & 5 \\
\hline & al Load Distance & & 175 & & 165 \\
\hline
\end{tabular}

Berdasarkan hasil perhitungan dan analisis weighted distance untuk masing - masing hubungan antar departemen diperoleh nilai Load distance untuk current block plan yaitu LD=175 sedangkan untuk proposed block plan diperoleh nilai Load Distance sebesar LD=165. Dari nilai ini maka dapat disimpulkan bahwa proposed block plan pertama dapat diterima karena nilai LD proposed block plan lebih kecil jika dibandingkan dengan LD Current block plan. Nilai load distance yang lebih kecil menunjukkan diperolehnya efisiensi karena beban kerja selama kegiatan akan lebih rendah dikarenakan jarak antar departemen yang saling berkaitan lebih dekat dan jarak departemen yang tidak berkaitan lebih jauh.

\subsection{Analisis Travel Time}

Untuk menggetahui minimasi travel time yang terjadi pada layout alternatif maka perlu dilakukan perhitungan travel time untuk layout awal. Karena travel time merupakan waktu total dalam kegiatan stuffing, maka definisi travel time merupakan akumulasi dari waktu tempuh dan lama proses kegiatan pada masing - masing departemen, sehingga rumus diatas dapat diturunkan menjadi sebagai berikut : 
$\mathrm{T} \operatorname{total}(1,2)=\mathrm{T}$ proses $(1,2)+\mathrm{T}$ waktu tempuh $(1,2)$

Dengan, T Proses $(1,2)=\frac{2 X(1,2)}{v(1)+v(2)}$

$\mathrm{T}(1,2)=\frac{2 D(1,2)}{v(1)+v(2)}+\mathrm{T}$ waktu tempuh

dengan $\mathrm{V}(1)=\frac{X 1}{t 1}, \mathrm{~V}(2)=\frac{X 2}{t 2}$

maka diperoleh rumus lengkap untuk travel time yaitu :

$\mathrm{T}(1,2)=\frac{2 D(1,2)}{\frac{X 1}{t 1}+\frac{X 2}{t 2}}+\mathrm{T}$ waktu tempuh

Diketahui :

$\mathrm{Tt}$

$\mathrm{Tp}$

T waktu tempuh

$\mathrm{D}$

$\mathrm{V}(1)$

$\mathrm{V}(2)$

$\mathrm{X} 1$

$\mathrm{X} 2$

t1

t2

$=$ travel time total $(\mathrm{s})$

=waktu proses kegiatan $(\mathrm{s})$

=waktu tempuh antar departemen (s)

$=$ Jarak antar departemen $(\mathrm{m})$

$=$ Kecepatan proses kegiatan di departemen $1(\mathrm{~m} / \mathrm{s})$

$=$ Kecepatan proses kegiatan di departemen $1(\mathrm{~m} / \mathrm{s})$

=Panjang ruangan departemen (1)

$=$ Panjang ruangan departemen (2)

=waktu proses kegiatan dertemen (1)

=waktu proses kegiatan departemen (2)

Berdasarkan rumus diatas maka dapat diperoleh hasil perhitungan travel time sesuai alur kegiatan stuffing untuk layout awal di PT IJS yaitu sebagai berikut :

Tabel 6 Perhitungan Travel Time layout awal

\begin{tabular}{cccccccccccc}
\hline $\mathrm{D} 1$ & $\mathrm{D} 2$ & $\begin{array}{c}\mathrm{D}(1,2) \\
(\mathrm{m})\end{array}$ & $\begin{array}{c}\mathrm{X}(1) \\
(\mathrm{m})\end{array}$ & $\begin{array}{c}\mathrm{X}(2) \\
(\mathrm{m})\end{array}$ & $\begin{array}{c}\mathrm{t}(1) \\
(\mathrm{s})\end{array}$ & $\begin{array}{c}\mathrm{t}(2) \\
(\mathrm{s})\end{array}$ & $\begin{array}{c}\mathrm{V}(1) \\
(\mathrm{m} / \mathrm{s})\end{array}$ & $\begin{array}{c}\mathrm{V}(2) \\
(\mathrm{m} / \mathrm{s})\end{array}$ & $\begin{array}{c}\mathrm{T}(1,2) \\
\mathrm{p} \\
(\mathrm{s})\end{array}$ & $\begin{array}{c}\mathrm{T}(1,2) \\
\mathrm{t}(\mathrm{s})\end{array}$ & $\begin{array}{c}\mathrm{T}(1,2) \\
\text { total }(\mathrm{s})\end{array}$ \\
\hline $\mathrm{A}$ & $\mathrm{C}$ & 1 & 25 & 15 & 300 & 600 & 0,83 & 0,250 & 18 & 60 & 78 \\
$\mathrm{C}$ & $\mathrm{E}$ & 2 & 15 & 75 & 600 & $\begin{array}{c}360 \\
0\end{array}$ & $\begin{array}{c}0,25 \\
0\end{array}$ & 0,208 & 87 & 120 & 207 \\
$\mathrm{E}$ & $\mathrm{F}$ & 2 & 75 & 35 & 3600 & 300 & 0,20 & 0,116 & 29 & 100 & 129 \\
$\mathrm{~F}$ & $\mathrm{H}$ & 1 & 35 & 50 & 300 & $\begin{array}{c}360 \\
8\end{array}$ & $\begin{array}{c}0,11 \\
6\end{array}$ & 0,139 & 15 & 70 & 85 \\
$\mathrm{G}$ & $\mathrm{H}$ & 1 & 20 & 50 & 1800 & $\begin{array}{c}360 \\
0\end{array}$ & $\begin{array}{c}0,11 \\
1\end{array}$ & 0,139 & 80 & 60 & 140 \\
$\mathrm{H}$ & $\mathrm{G}$ & 1 & 50 & 20 & 3600 & $\begin{array}{c}180 \\
0\end{array}$ & $\begin{array}{c}0,13 \\
9\end{array}$ & 0,111 & 80 & 60 & 140 \\
$\mathrm{G}$ & $\mathrm{B}$ & 3 & 20 & 30 & 1800 & $\begin{array}{c}180 \\
0\end{array}$ & 0,11 & 0,167 & 216 & 180 & 396 \\
\hline
\end{tabular}


Tabel 6 Perhitungan Travel Time layout awal

\begin{tabular}{cccccccccccc}
\hline $\mathrm{D} 1$ & $\mathrm{D} 2$ & $\mathrm{D}(1,2)$ & $\mathrm{X}(1)$ & $\mathrm{X}(2)$ & $\mathrm{t}(1)$ & $\mathrm{t}(2)$ & $\mathrm{V}(1)$ & $\mathrm{V}(2)$ & $\mathrm{T}(1,2)$ & $\mathrm{T}(1,2)$ & $\mathrm{T}(1,2)$ \\
& & $(\mathrm{m})$ & $(\mathrm{m})$ & $(\mathrm{m})$ & $(\mathrm{s})$ & $(\mathrm{s})$ & $(\mathrm{m} / \mathrm{s})$ & $(\mathrm{m} / \mathrm{s})$ & $\mathrm{p}$ & $\mathrm{t}(\mathrm{s})$ & total (s)
\end{tabular}

(s)

\begin{tabular}{cccccccccccc}
\hline $\mathrm{B}$ & $\mathrm{D}$ & 1 & 30 & 30 & 1800 & 600 & 0,167 & 0,500 & 30 & 60 & 90 \\
$\mathrm{D}$ & $\mathrm{G}$ & 2 & 30 & 20 & 600 & 1800 & 0,500 & 0,111 & 65 & 120 & 185 \\
$\mathrm{G}$ & $\mathrm{C}$ & 4 & 20 & 15 & 1800 & 600 & 0,111 & 0,250 & 222 & 250 & 472 \\
$\mathrm{C}$ & $\mathrm{A}$ & 1 & 15 & 25 & 600 & 300 & 0,250 & 0,833 & 18 & 60 & 78 \\
\multicolumn{2}{c}{ Total } & 19 & 335 & 365 & 16800 & 18600 & 0,384 & 0,387 & 862 & 1140 & 2002 \\
\hline
\end{tabular}

Diketahui hasil perhitungan travel time pada layout awal yaitu $\mathrm{T}=2002$ sekon, selanjutnya hasil ini dibandingkan dengan travel time pada layout alternatif. Pada layout alternatif terjadi perubahan waktu tempuh karena perpindahan departemen $\mathrm{B}$ dengan departemen $\mathrm{F}$ yang berpindah posisi atau letaknya, dihitung total travel time pada layout alternatif dengan mengggunakan rumus yang sama maka diperoleh hasil perhitungan sebagai berikut :

Tabel 7 Perhitungan Travel Time layout Alternatif

\begin{tabular}{cccccccccccc}
\hline $\mathrm{D} 1$ & $\mathrm{D} 2$ & $\mathrm{D}(1,2)$ & $\mathrm{X}(1)$ & $\mathrm{X}(2)$ & $\mathrm{t}(1)$ & $\mathrm{t}(2)$ & $\mathrm{V}(1)$ & $\mathrm{V}(2)$ & $\mathrm{T}(1,2)$ & $\mathrm{T}(1,2)$ & $\mathrm{T}(1,2)$ \\
& & $(\mathrm{m})$ & $(\mathrm{m})$ & $(\mathrm{m})$ & $(\mathrm{s})$ & $(\mathrm{s})$ & $(\mathrm{m} / \mathrm{s})$ & $(\mathrm{m} / \mathrm{s})$ & Proses & tempuh & total
\end{tabular}

(s) (s) (s)

\begin{tabular}{|c|c|c|c|c|c|c|c|c|c|c|c|}
\hline A & $\mathrm{C}$ & 1 & 25 & 15 & 300 & 600 & 0,833 & 0,250 & 18 & 60 & 78 \\
\hline $\mathrm{C}$ & E & 2 & 15 & 75 & 600 & 3600 & 0,250 & 0,208 & 87 & 120 & 207 \\
\hline $\mathrm{E}$ & $\mathrm{F}$ & 1 & 75 & 30 & 3600 & 300 & 0,208 & 0,167 & 15 & 60 & 75 \\
\hline $\mathrm{F}$ & $\mathrm{H}$ & 4 & 35 & 50 & 300 & 3600 & 0,117 & 0,139 & 61 & 190 & 251 \\
\hline G & $\mathrm{H}$ & 1 & 20 & 50 & 1800 & 3600 & 0,111 & 0,139 & 80 & 60 & 140 \\
\hline $\mathrm{H}$ & G & 1 & 50 & 20 & 3600 & 1800 & 0,139 & 0,111 & 80 & 60 & 140 \\
\hline G & B & 1 & 20 & 35 & 1800 & 1800 & 0,111 & 0,167 & 72 & 60 & 132 \\
\hline B & D & 1 & 35 & 30 & 1800 & 600 & 0,167 & 0,500 & 30 & 60 & 90 \\
\hline D & G & 2 & 30 & 20 & 600 & 1800 & 0,500 & 0,111 & 65 & 120 & 185 \\
\hline G & $\mathrm{C}$ & 4 & 20 & 15 & 1800 & 600 & 0,111 & 0,250 & 222 & 250 & 472 \\
\hline $\mathrm{C}$ & A & 1 & 15 & 25 & 600 & 300 & 0,250 & 0,833 & 18 & 60 & 78 \\
\hline \multicolumn{2}{|c|}{ Total } & 19 & 335 & 365 & 16800 & 18600 & 0,384 & 0,387 & 749 & 1100 & 1849 \\
\hline
\end{tabular}

Berdasarkan hasil perhitungan travel time diatas maka diperoleh nilai travel time pada alternatif layout yaitu $\mathrm{T}=1849$ sekon. Dari hasil ini jika dibandingkan dengan travel time pada layout awal yaitu $\mathrm{T}=2002$ sekon yang lebih besar sehingga diperoleh minimasi travel time sebesar 153 sekon jika layout alternatif diterapkan.

Hasil analisis perhitungan dalam penelitian ini dibatasi ruang lingkup pembahasan menggenai travel time. Faktor eksternal lain yang dapat mempengaruhi efektifitas hasil perhitungan seperti 
biaya, tenaga, dan sumber daya dianggap diabaikan. Keunggulan dari metode weighted distance yaitu lebih mudah diterapkan dalam penentuan layout karena didukung proses pembuatan block plan, sedangkan keterbatasan dari metode ini yaitu kurang terperinci menggenai hasil perhitungan sehingga menghasilkan layout baru yang hanya mempertimbangkan faktor jarak.

\section{Kesimpulan}

Berdasarkan hasil pengolahan data dan pembahasan, penelitian ini menghasilkan sebuah layout alternatif usulan untuk PT IJS yang dapat memaksimalkan kegiatan loading barang di dalam gudang. Perhitungan travel time pada layout awal sebesar T=2002 sekon sedangkan layout alternatif menghasilkan nilai $\mathrm{T}=1849$ sekon, hal ini menunjukkan bahwa layout alternatif usulan berhasil meminimasi travel time. Berdasarkan penelitian, diketahui bahwa metode weighted distance dapat diterapkan untuk membuat rancangan layout gudang dengan menghasilkan travel time yang lebih singkat. Perlu adanya penelitian lebih lanjut menggenai efektifitas hasil perhitungan travel time terhadap biaya yang harus dikeluarkan untuk melakukan relayout.

\section{REFERENSI}

[1] Apple, James. Tata Letak Perusahaan Dan Pemindahan Bahan. ITB Bandung. 1990

[2] Haqqi, Rijalul. Analisis Waktu Tempuh Kendaraan Bermotor dengan Metode Estimasi Instantaneous Model. FJOMTEKNIK, FakultasTeknik Univeristas Riau, Vol. IV, No. 2. (2017)

[3] Hidayat, N.P. A. Perancangan Tata Letak Gudang dengan Metode Class Based Storage Studi kasus CV. SG Bandung. Jurnal Al-Azhar Indonesia seri sains dan teknologi. 1(3): 105-115. 2012.

[4] Johan, Suhada, K. Usulan Perancangan tata letak gudang dengan menggunakan metode class-based storage (studi kasus di PT Heksatex Indah , Cimahi Selatan). Jurnal manajemen Industri dan Logsitik. Politeknik APP Jakarta. 10(10): 52-71.2018

[5] Liu, C.M.Optimal Storage Layout and Order Picking for Warehousing. International Journal of Operation and Research. 1(1): 37-46. 2004

[6] Lukmandono. And Faizal, R. Desain Relayout Warehouse dengan Pendekatan SLP (Systematic Layout Palnning) dan Class Based Storage Untuk Meminimumkan Biaya Material Handling. Semnas Sains dan Teknologi Terapan VI. Insitut Teknologi Adhi Tama Surabaya. 2017

[7] Muslim, D. and Ilmaniati, A. Jarak dan ongkos material handling dengan pendekatan systematic layout planning (SLP) di PT Transplant Indonesia. JMTSI. 2(1): 45-52. 2018

[8] Pratiwi, I., Muslimah, E. And Aqil, A. W. Perancangan Tata Letak Fasilitas di Industri Tahu Menggunakan Blocplan. Jurnal Ilmiah teknik Industri. 11(2): 102-112. 2012 
[9] Zhenyuan, J., Xiaohong, L., Wang, W., Defeng, J., dan Lijun, W. Design and Implementation of Lean Facility Layout System of Production Line. International Journal of Industrial Engineering. 18(5): 260-269. 2011

[10] Ahyari, Agus, Manajemen Produksi : Perencanaan Letak Fasilitas Pabrik, Perencanaan Lingkungan Kerja, dan Perencanaan Standar Produksi, Penerbit BPFE, Yogyakarta, 1986 